\title{
Analysis Of The 21st Century Skills Achievement Using Constructivist Learning With Arduino Based Driverless Vehicle Technology
}

\author{
$1^{\text {st }}$ Azinudin Achzab \\ The Faculty of Teacher Training \\ and Education \\ Universitas SebelasMaret \\ Indonesia \\ azinudinachzab@student.uns.ac.id
}

\author{
$2^{\text {nd }}$ Cucuk Wawan Budiyanto \\ The Faculty of Teacher Training \\ and Education \\ Universitas SebelasMaret \\ Indonesia
}

\author{
$3^{\text {rd }}$ Aris Budianto \\ The Faculty of Teacher Training \\ and Education \\ Universitas SebelasMaret \\ Indonesia
}

\begin{abstract}
There has been recent attention to science, technology, engineering, and math (STEM) learning for early age children. Furthermore, the development of new technology learning standards and methods for integrating it into early age children education have been improved. Teacher-centred learning, information through lectures, relies on the use of whiteboards or reading materials recommended by teachers, causes passive students and such an approach can not address the challenges of the global economic era in educational processes and lacks equipping students with 21st-century skills needed recently. This paper reports preliminary findings on the robotics learning tools such as Arduino-based driverless vehicle technology influences student' perception of the 21stcentury skills pertinent to technological and vocational education and training (TVET) learning circumstances using a descriptive-qualitative research design. Two out of 100 target participants involved in this research, purposive sampling trough students with TVET learning environment. Interview such as open-ended and closed interview used to collecting the data and resulting in findings that indicate the correlation between student's achievement on 21 st-century skills and constructivist learning environment.
\end{abstract}

Keywords-21st Century Skills, Constructivist Learning, Driverless Vehicle, TVET, 4Cs

\section{INTRODUCTION}

Constructivist learning is an approach on teaching and learning based on the premise that cognition (learning) is the result of "mental construction" or in other words, the learners learn by enhancing the knowledge they already know with new information. Constructivist learning follows the principle that learning is also affected by the context in which an idea is taught as well as by students' beliefs and attitudes ${ }^{[1]}$. The theory of constructivism asserts that social interaction plays a fundamental role in cognitive development. While robotics has the potential to be used in a social context, constructivist learning can be used as a base in the learning process supported by robots ${ }^{[2]}$.

Robotics in education has emerged as an projectbased interdisciplinary learning activities that are heavily linked to the STEM concept and offer new benefits to education at all levels ${ }^{[3]}$ especially on technological and vocational education and training (TVET) where students are prepared to have $21 \mathrm{st}$ century skills before work. 21 st skills is important to be achieved in the scope of education because it was a standard of graduate competence in order to live independently and follow further education, the preparation involves learners to have solid knowledge and skills and TVET curricula,programs must take the challenge of developing good real-world problem solving activities for their students. To help students develop "good problem solving skills". It also means that learners should be equipped with 21 st century skills that include: STEM, problem solving, critical thinking, communication, collaboration and creativity (Four 4Cs) and other normative elements such as cultural awareness, consumerism, privacy and security, and what it means to being a good person and citizen ${ }^{[4]}$.

Teacher-centered learning, information through lectures, relies on the use of whiteboards or reading materials recommended by teachers, causes passive students and such an approach can not address the challenges of the global economic era in educational processes and lacks equipping students with $21 \mathrm{st}-$ century skills needed recently ${ }^{[2]}$. The learning activities such as analyzing driverless vehicle structure, modifying arduino code and simple quiz exploring the possibility of 21 st century achievement using robot as educational agent.

This research explores the possibility of the $21 \mathrm{st}$ century skills achievement through constructivist learning using arduino based driverless vehicle. The 
21st century skills evaluated in this research comprises creativity, critical thinking, communication, and collaboration which are abbreviated as 4Cs (Four Cs). To facilitate the exploration over participant achievement of $4 \mathrm{Cs}$, the researchers adopted constructivist learning step using Koohang'stheory ${ }^{[5]}$. Although the design of research was covering overarching aspects of learning, the research is preliminary to the extent that the article reports the analysis of findings from a handful of research participants attending the sessions.

\section{A. Conceptual Background}

\section{Constructivist Learning - Constructivist} principles provide a set of guiding principles to help designers and teachers create learner-centered, collaborative environments that support reflective and experiential processes. Students and instructors can then build meaning, understanding, and relevant practice together and go far beyond the mere movement of information from instructors' minds to students' notebooks ${ }^{[6]}$. Piaget adds that learning builds on each individual experience and the relationship between previously learned concepts and new ideas. This leads to the idea of disequilibrium, which encourages the learning process. Piaget's disequilibrium theory explains when new ideas and concepts do not match what one knows. Therefore, one is forced to adjust one's thinking to incorporate this new information. Piaget's conception of equilibrium implies the dynamic construction process of the human cognitive structure. Thus, Piaget explained that the construct of knowledge is done by the learners themselves or in other words individual construct $^{[7]}$.

Koohang's Constructivist Learning StepAccording to Koohang, constructivist learning following nine steps:

1) Goals Identification: The objectives in learning will give direction in program design, implementation and evaluation.

2) Preparing the learning product's content: At this step, concepts and principles of learning which should be mastered by students are settled in teaching materials.

3) Identify Initial Knowledge of Students: Identification of initial knowledge of students can be done through preliminary tests, interviews and concept maps.

4) Identify Student Misconception: The student's initial knowledge that has been identified and clarified needs to be further analyzed to determine which of them is wrong and which are misconceptions.

5) Learning Planning and Strategy: The learning program is described in the shape of learning implementation plan. While the strategy of changing student's conception is realized in teaching materials.

6) Implementation of Learning Program:At this step, the actual activity in the classroom. This stage consists of three steps: orientation and presentation of learning experiences, exploring student ideas, restructuring ideas.

7) Evaluation: The evaluation of the effectiveness of the learning model has been applied.

8) Clarification and Analysis of Student's Resistant Misconceptions: The identification of students's misconception, clarification and analysis of student misconception compared to the result of evaluation created an information of resistant misconceptions of students.

9) Revision of Misconception Strategy:The result of resistant misconception analysis is used as a consideration in revising the strategy of changing student conception in teaching material.

Arduino Based Driverless Vehicle-Autonomous cars (also known as driverless cars, self-propelled cars, robotic cars $)^{[8]}$ and driverless land vehicles are vehicles capable of sensing the environment and navigating without human inpu ${ }^{[9]}$. driverless cars are vehicles that are adept at feeling the environment and navigating without human involvement. Google with an automated car operated by its AI software named Google Chauffeur and Tesla with an autopilot system on Tesla Model S designed to be a wheeled computer is already working to make this car publicly available.

Arduino is an open-source physical computing platform based on simple input/output (I / O) boards and a development environment that implements Processing Language. Arduino can be used to develop stand-alone interactive objects or can be connected integrally to software on the computer (such as Flash, Processing, VVVV, or Max / MSP). Arduino can be assembled independently or purchased in final form, Arduino's IDE (Integrated Development Environment) is open source and can be downloaded for fre ${ }^{[10]}$.

\section{METHOD}

This study is based on qualitative approach ${ }^{[11]}$, our goal is it could use qualitative data to exploring the possibility of 21 st-century achievement using a driverless vehicle as an educational agent. A short lesson and exploring the driverless vehicle has given to the subject to find reliable data based on method approach. However, we decide to use some challenges to the participant because we believe that constructivist learning will appear in their experience.

The Participant is a group of 2 peoples $(1$ male and 1 female). The participant itself is 2 students with TVET learning environment and have interest of driverless vehicle and robotics, the participant were able to explore freely without any limit of the times.In this study, the data used are qualitative data, presented in the form of verbal words, not in the form of numbers ${ }^{[12]}$. Including qualitative data in this study is a general overview of participant learning experiences when using Arduino-based driverless vehicle technology in a constructivism learning environment. Researcher uses the primary data source in this research, that is the result of observation and interview from the participant of the group. 
A group of participant asked to complete 8 sessions to finish the interview and observation. 1st session is the introduction of the research and the driverless vehicle. 2nd session learning through the written learning material. 3rd session is a communication skill quiz. 4th session is a deep discussion about the driverless vehicle and Arduino technology. 5th session is the core session where the participant asked to freely explore the driverless vehicle and the coding on Arduino. 6th session is participant could make a modification to the driverless vehicle and the coding on Arduino. 7th session is a short break and creativity quiz. The last session, the participant asked to do a survey to measure their collaboration skill and critical thinking quiz. The session has done privately, so the researcher can see the perspective of each respondent.

\section{PRELIMINARY RESUlT}

This research was a work to integrate robotics into ordinary teaching and learning in a TVET environment. Students of an informatics department were selected purposively for their familiarity with the context or in other words, have an interest on driverless vehicle and robotics. Apart from the condition that the use of robotics such as driverless vehicle was relatively novel. The group of participant comprised of two peoples in a group. Their identities are presented in Table 1.

TABLE I. PARTICIPANT IDENTITIES

\begin{tabular}{|l|l|l|}
\hline Participant ID & Gender & Grade \\
\hline A & Male & $4^{\text {th }}$ Year \\
\hline B & Female & $2^{\text {nd }}$ Year \\
\hline
\end{tabular}

The following is a report of the visual observation on each participant's responses of the interview and observation session:

\begin{tabular}{|c|c|c|c|c|}
\hline \multirow{2}{*}{$\begin{array}{l}\text { Partici } \\
\text { pant } \\
\text { Code }\end{array}$} & \multicolumn{4}{|c|}{ 4C's Aspect } \\
\hline & Creativity & $\begin{array}{l}\text { Critical } \\
\text { Thinking }\end{array}$ & $\begin{array}{l}\text { Communicat } \\
\text { ion }\end{array}$ & $\begin{array}{l}\text { Collabora } \\
\text { tion }\end{array}$ \\
\hline
\end{tabular}

\begin{tabular}{|c|c|c|c|c|}
\hline $\mathrm{A}$ & $\begin{array}{l}\text { •Interview: } \\
\text { Said a } \\
\text { many } \\
\text { common } \\
\text { functions } \\
\text { of } \\
\text { driverless } \\
\text { vehicle } \\
\text { and } \\
\text { Arduino } \\
\text { but the } \\
\text { explanatio } \\
\text { n rich of } \\
\text { detail such } \\
\text { as how the } \\
\text { functions } \\
\text { work and } \\
\text { the best } \\
\text { way to } \\
\text { implement } \\
\text { it. } \\
\text { •Observatio } \\
\text { n: On the } \\
\text { 5th session } \\
\text { the } \\
\text { participant } \\
\text { A played } \\
\text { the } \\
\text { driverless } \\
\text { vehicle in } \\
\text { a short } \\
\text { time but } \\
\text { made a lot } \\
\text { of } \\
\text { modificati } \\
\text { on on } \\
\text { Arduino } \\
\text { code and } \\
\text { giving a } \\
\text { new fresh } \\
\text { idea to } \\
\text { driverless } \\
\text { vehicle } \\
\text { future } \\
\text { developme } \\
\text { nt. } \\
\end{array}$ & $\begin{array}{l}\text {-Interview: } \\
\text { Participant } \\
\text { A shown a } \\
\text { high } \\
\text { interest on } \\
\text { analysing } \\
\text { why thing } \\
\text { works, not } \\
\text { feel } \\
\text { confused } \\
\text { on clearing } \\
\text { all quiz and } \\
\text { challenge } \\
\text { given and } \\
\text { believed } \\
\text { every } \\
\text { theory need } \\
\text { to be } \\
\text { evaluated. } \\
\text {-Observatio } \\
\text { n: } \\
\text { Participant } \\
\text { A provides } \\
\text { one } \\
\text { experiment } \\
\text { al design } \\
\text { on solving } \\
\text { problem, } \\
\text { have } \\
\text { several } \\
\text { perception } \\
\text { on } \\
\text { arguments, } \\
\text { trying } \\
\text { several } \\
\text { solution to } \\
\text { a problem } \\
\text { and found a } \\
\text { direct } \\
\text { connection } \\
\text { between } \\
\text { things. }\end{array}$ & $\begin{array}{l}\text {-Interview: } \\
\text { Showing } \\
\text { empathy to } \\
\text { others, } \\
\text { preferring } \\
\text { direct } \\
\text { communicat } \\
\text { ion and not } \\
\text { forcing his } \\
\text { belief to } \\
\text { others. } \\
\text { - Observation } \\
\text { : Participant } \\
\text { A not talk } \\
\text { to much } \\
\text { during all } \\
\text { sessions, he } \\
\text { showing a } \\
\text { respect to } \\
\text { other } \\
\text { opinions } \\
\text { and } \\
\text { contribution } \\
\text { but never } \\
\text { initiating a } \\
\text { conversatio } \\
\text { n. }\end{array}$ & $\begin{array}{l}\text { - Intervie } \\
\text { w:Partic } \\
\text { ipant A } \\
\text { trust his } \\
\text { work } \\
\text { partner } \\
\text { but } \\
\text { have a } \\
\text { little } \\
\text { problem } \\
\text { on } \\
\text { expressi } \\
\text { ng } \\
\text { himself. } \\
\text { Particip } \\
\text { ant A } \\
\text { always } \\
\text { do the } \\
\text { challen } \\
\text { ge } \\
\text { given } \\
\text { alone, } \\
\text { he } \\
\text { continui } \\
\text { ng the } \\
\text { other } \\
\text { particip } \\
\text { ant } \\
\text { works } \\
\text { but not } \\
\text { showin } \\
\text { g a sign } \\
\text { of } \\
\text { teamwo } \\
\text { rk there. }\end{array}$ \\
\hline B & $\begin{array}{l}\text { - Interview: } \\
\text { Said } \\
\text { uncommo } \\
\text { n function } \\
\text { of } \\
\text { driverless } \\
\text { vehicle but } \\
\text { doesn't } \\
\text { know the } \\
\text { alternative } \\
\text { uses of } \\
\text { Arduino. } \\
\text { - Observatio } \\
\text { n: On the } \\
\text { 5th session } \\
\text { the } \\
\text { participant } \\
\text { B asked to } \\
\text { ride the } \\
\text { driverless } \\
\text { vehicle it's } \\
\text { shown that } \\
\text { the } \\
\text { participant } \\
\text { have a } \\
\text { desire to } \\
\text { do } \\
\text { something } \\
\text { out of } \\
\text { instruction } \\
\text {. A low } \\
\text { experience } \\
\text { of Arduino }\end{array}$ & $\begin{array}{l}\text {-Interview: } \\
\text { Participant } \\
\text { B shown a } \\
\text { moderate } \\
\text { interest on } \\
\text { analysing } \\
\text { why thing } \\
\text { works, feel } \\
\text { a little } \\
\text { confused } \\
\text { on clearing } \\
\text { all quiz and } \\
\text { challenge } \\
\text { given and } \\
\text { believed } \\
\text { every } \\
\text { theory need } \\
\text { to be } \\
\text { evaluated. } \\
\text { •Observatio } \\
\text { n: Can't } \\
\text { explaining } \\
\text { even one } \\
\text { experiment } \\
\text { al design, } \\
\text { have } \\
\text { several } \\
\text { perception } \\
\text { on } \\
\text { arguments, } \\
\text { trying one } \\
\text { solution to } \\
\text { a problem }\end{array}$ & $\begin{array}{l}\text {-Interview: } \\
\text { Showing } \\
\text { care and } \\
\text { empathy to } \\
\text { others, } \\
\text { preferring } \\
\text { direct } \\
\text { communicat } \\
\text { ion, prefer a } \\
\text { body } \\
\text { language on } \\
\text { communicat } \\
\text { ion and } \\
\text { want other } \\
\text { to } \\
\text { understand } \\
\text { her belief. } \\
\text {-Observation } \\
\text { : Participant } \\
\text { B was } \\
\text { talkative } \\
\text { when asked } \\
\text { but remain } \\
\text { silent when } \\
\text { was not } \\
\text { asked to } \\
\text { answer } \\
\text { anything, } \\
\text { she showed } \\
\text { a respect to } \\
\text { others' } \\
\text { opinions } \\
\text { and }\end{array}$ & $\begin{array}{l}\text { Interview } \\
\text { : } \\
\text { Participan } \\
\text { t B trust } \\
\text { his work } \\
\text { partner } \\
\text { but have } \\
\text { a problem } \\
\text { on } \\
\text { trusting } \\
\text { herself. } \\
\text { - Observati } \\
\text { on: } \\
\text { Participan } \\
\text { t B } \\
\text { waiting } \\
\text { the other } \\
\text { to do the } \\
\text { challenge } \\
\text { given, she } \\
\text { observe } \\
\text { how } \\
\text { things } \\
\text { work first } \\
\text { then do it } \\
\text { alone. } \\
\text { Her face } \\
\text { showing } \\
\text { a sign of } \\
\text { a need to } \\
\text { guided by } \\
\text { the }\end{array}$ \\
\hline
\end{tabular}




\begin{tabular}{|l|l|l|l|l|}
\hline $\begin{array}{l}\text { made her } \\
\text { not do } \\
\text { much on } \\
\text { coding }\end{array}$ & $\begin{array}{l}\text { and waiting } \\
\text { other to fix } \\
\text { it, and } \\
\text { found } \\
\text { indirect } \\
\text { connection } \\
\text { between } \\
\text { things. }\end{array}$ & $\begin{array}{l}\text { contribution } \\
\text { and } \\
\text { sometimes } \\
\text { initiating a } \\
\text { conversatio } \\
\text { n. }\end{array}$ & others. \\
& & & & \\
& & & & \\
& & & & \\
& & & & \\
& & & & \\
& & & & \\
& & & & \\
& & & \\
& & & \\
& & & \\
\end{tabular}

\section{DISCUSSION}

Every 4C's of 21 st century skills aspect have been analyzed to get a brief explanation about how far the participants achieving the 21 st century skills, and the results are:

1) Creativity: Participant A show a moderate creativity expressing the originality of a new idea but strong on explaining the elaboration and fluency of how things work. Participant B is the opposite of participant A where the idea originality of participant B showing a high creativity but she can't give a brief

\section{CONCLUSION}

The result above concluded that driverless vehicle have a good potential on helping participant to achieving $21 \mathrm{st}$ century skills although some cognitive aspect is missing on this research but as long as the research continue the best way to including it will explained itself. The research show how the participant experiencing an uncommon model of learning and evaluate their preparation to work in this era through constructivist learning using Arduino based driverless vehicle. Constructivist learning method is recommend to implemented in school curriculum and learning design to help the student achieving 21 st skills while a research to look how far it works or statistical result about the result are needed.

\section{REFERENCES}

[1] Olusegun, S. (2015). Constructivism Learning Theory: A Paradigm for Teaching and Learning. IOSR Journal of Research \& Method in Education Ver. I, 5(6), 2320-7388. https://doi.org/10.9790/7388-05616670

[2] Bii, P. (2013). Chatbot technology: A possible means of unlocking student potential to learn how to learn. Educational Research (ISSN: 2141-5161), 4(February), 218-221. Retrieved from http://interesjournals.com/ER/pdf/2013/February/Bii.pdf

[3] Alimisis, D. (2012). Robotics in Education \& Education in Robotics: Shifting Focus from Technology to explanation about the elaboration and fluency about the function. As the literature said ${ }^{[13]}$ participant A and $\mathrm{B}$ potentially creating a new idea trough their creativity, the difference is participant A can expressing the idea better than participant B. While the second literature ${ }^{[14]}$ said that participant $B$ have better creativity because she has an unexpected idea when brainstorming or usually called by "out of the box". But the most important thing was both of them still have their own kind of creativity.

2) Critical Thinking:Participant A categorized as owner of positive thinking mindset while participant B categorized as owner of inconsistent thinking mindset. The category is not to summarize but to give a deep explanation on how the participant behave when they're facing a problem ${ }^{[15]}$. Both participant can't show a lot of experimental design on solving problem but they're showing a high level of analysingan arguments.

3) Communication:Participant $\mathrm{A}$ have a higher interview's communication skill than participant B but in daily conversation / light common conversation participant B show more effectiveness and empathy while talking to others than participant A. Which mean participant A show a good potential to become good worker while participant B show a good potential to become a good leader.

4) Collaboration:Both participant show a little problem on expressing them self and can be described as lack of self confidence but showing a big respect and trust to their partner on work.

Pedagogy. Proceedings of the 3rd International Conference on Robotics in Education, 7-14.

[4] Reeve, E. M. (2016). 21st century skills needed by students in technical and vocational education and training (TVET). Asian International Journal of Social Sciences, 16(4), 65-82.

[5] Koohang, A., Riley, L., Smith, T., \&Schreurs, J. (2009). E-learning and constructivism: From theory to application.

[6] Jonassen, D., Davidson, M., Collins, M., Campbell, J., \& Haag, B. B. (1995). Constructivism and computer-mediated communication in distance education. American journal of distance education, 9(2), 7-26.

[7] Piaget, J. (1970). Piaget's theory. In Carmichael's Manual of Child Psychology (pp. 703-720).

[8] Thrun, S. (2010). Toward robotic cars. Communications of the ACM, 53(4), 99. https://doi.org/10.1145/1721654.1721679

[9] Gehrig, S. K., \& Stein, F. J. (1999). Dead reckoning and cartography using stereo vision for an autonomous car. In Proceedings 1999 IEEE/RSJ International Conference on Intelligent Robots and Systems. Human and Environment Friendly Robots with High Intelligence and Emotional Quotients (Cat. No.99CH36289) (Vol. 3, pp. 1507-1512). https://doi.org/10.1109/IROS.1999.811692

[10] Banzi, M. (2011). Getting Started with Arduino, 2nd Edition - O'Reilly Media. 计算机 _004_编程. https://doi.org/10.1007/s13398-014-0173-7.2

[11] Miles, M. B., Huberman, A. M., \& Saldana, J. (2013). Qualitative Data Analysis: A Methods Sourcebook. 
SAGE Publications. $\quad$ Retrieved from https://books.google.co.id/books?id=p0wXBAAAQBAJ

[12] Ary, Donald. Et al. 2010 Introduction to Research in Education. Eight Edition. Canada: Nelson Education

[13] Starkweather EK, Azbill P. An exploratory study of preschool children's freedom of expression. Proc Oklahoma AcadSci-ence. 1965;45:176-80.

[14] Wilson RC, Guilford JP, Christensen PR. The Measurement of Individual Differences in Origi- nality. Psychol Bull. 1953;50(5):362.
[15] Facione PA, Facione NC, Blohm SW, Gi- ancarlo CAF. The California Critical Thinking Skills Test: CCTST. California Academic Press; 2002.

[16] Hargreaves, M. H., \& Grenfell, A. T. (2003, November). The use of assessment strategies to develop critical thinking skills in science. In ATN Evaluations and Assessment Conference. 